\title{
モリブデンの低温破断挙動に及ぼすレニウムと炭素添加の効果*
}

\author{
平岡裕 $* *$
}

J. Japan Inst. Metals, Vol. 56, No. 2 (1992), pp. 161-167

Effect of Rhenium and Carbon Additions on Low-Temperature

Fracture Behavior of Molybdenum*

\section{Yutaka Hiraoka**}

Effects of rhenium and carbon additions on the fracture strength, ductility and fracture mode of powder-metallurgy molybdenum at low temperatures were investigated.

The results are summarized as follows:

(1) Low-temperature fracture strength of molybdenum indicated a maximum at 10 mass $\%$ rhenium. Rhenium addition enhanced both intergranular and transgranular fracture strengths. Carbon addition further enhanced the intergranular fracture strength in addition to the rhenium effect.

(2) Low-temperature ductility of molybdenum seemed to indicate a maximum at 10-13 mass\% rhenium or more. This result is due to the lowering of yield strength as well as the increase of fracture strength. Further improvement of ductility by the carbon addition is due to the increase of intergranular fracture strength.

(3) The present results support the "rhenium effect" reported by Klopp et al. and Lundberg et al. Molybdenum containing 13 mass\% rhenium and 30 mass ppm carbon indicated a certain amount of ductility even at a temperature as low as $-196^{\circ} \mathrm{C}$.

(Received July 31, 1991)

Keywords: molybdenum, powder metallurgy, rhenium addition, carbon addition, low temperature, fracture strength, ductility, fracture mode

I . 緒言

1955年に Geach と Hughes ${ }^{(1)}$ がモリブデンおよびタン グステンの延性がレニウム添加により顕著に改善されるこ とを報告して以来, “レニウム効果” は多くの研究者にと って興味ある研究対象となってきた(2)-(9). しかしながら， レニウムはモリブデンに比べて比重が約 2 倍も大きく， また高価な金属である．さらにレニウムを多量に添加した 合金は成形加工性に劣ることが知られている．したがっ て，レニウムを少量添加した比較的希薄な Mo-Re 合金の 開発が実用性の観点から期待される.

Klopp, Witzke ら (7)(10)(11) は, 電子ビーム溶解法により 7.7 原子\%(13.9質量\%) までレニウムを添加した合金を試 作し，低温および高温での機械的特性を調べた．その結 果, 加工状態拉よび再結晶状態での材料の曲げあるいは引 張試験により求めた延性-脆性遷移温度はレニウム量の増 加に伴い低下し，7.7原子\%のレニウム量に括いて最も優 れた延性が得られることを示した。またレニウム添加によ り，モリブデンの高温に拈けるクリープ強度がかなり改善 できることも明らかにした。その後, Lundberg ら (9)(12)
は真空アーク溶解法により9.6原子\%(17.2質量\%) むでの レニウムを添加した合金を試作し，それらの再結晶特性， 機械的特性および破断挙動を調べた。そして, 7.4〜8.2 原子\%(13.4〜 14.8質量\%)のレニウム添加により，比較 的低温に打ける(たとえばー $\left.118^{\circ} \mathrm{C}\right)$ 延性が改善されること を報告した。しかしながら，最近 Wadsworthら ${ }^{(13)}$ は Lundberg らの実験結果を再吟味し, 彼らの固溶軟化に基 づいた延性改善は説得力に欠けるものであり,このような 結果がレニウム量ではなくてむしろ炭素と酸素の原子量比 $\mathrm{C} / \mathrm{O}$ によって解釈できることを示唆した.すなわち, Lundberg らの研究に打ける延性の極大は, 原子量比 C/ Oといった組成の違い拈よび再結晶処理温度の違いに起 因した結晶粒径の違いなどにより結果的に出現したもので あり，本質的なものでないと指摘した。

本研究に和いては，粉末治金法によりレニウムを 2,4 , 10,13質量\%添加した 4 種類の Mo-Re 合金板を試作し, $-196^{\circ} \mathrm{C}$ か $25^{\circ} \mathrm{C}$ 温度範囲で引張試験を行い, モリブデ ンの破断挙動(強度・延性, 破断様相など) に及ぼすレニウ ム添加の効果就よびレニウムと炭素の複合添加の効果を検 討した.

*1991年 4 月, 10月日本金属学会春期括よび秋期大会に発表

** 岡山理科大学大学院理学研究科 (Graduate School of Science, Okayama University of Science, Okayama) 


\section{II. 実 験 方 法}

本研究に用いた材料は，粉末冶金法に上り試作した板厚 約 $1 \mathrm{~mm}$ の 4 種類のモリブデンーレニウム $(2,4,10,13$ 質量 \%)合金である、比較材として同じく粉末治金法により製 造した純モりブデン板を用いた。化学組成を Table 1 K 示すが，モッブデンの低温延性に大きな影響を及ばすこと が知られている酸素, 炭素量はそれぞれ14 23質量 ppm, 4〜12質量 ppmであり，村料間炕ある大きな差は なかった。これらの材料上り, 平行部の寸法が幅 $4 \mathrm{~mm}$, 長さ $14 \mathrm{~mm}$ の引張試験片を機械加工により切り出した. 試験片の表面をエメリ一紙を用いて研磨した後, 電解研磨 に供した。電解研磨液はメチルアルコールと硫酸を 85 : 15 の容積比で混ぜ合わせたものである。さらに試験前の 熱処理として $1.3 \times 10^{-4} \mathrm{~Pa}$ の真空中, $1500^{\circ} \mathrm{C} て ゙ 3.6 \mathrm{ks}$ の再結晶処理(再結晶処理材)を行った. 再結晶処理材の平

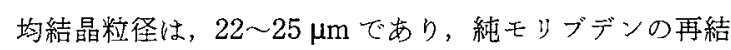
晶処理材 $\left(20 \sim 30 \mu \mathrm{m}^{(14)(15)}\right)$ 上同程度であった。 また少量 の炭素を添加するために, 再結晶後浸炭処理 (浸炭処理材) を行った。浸炭処理は, 試験片の表面に炭素を真空蒸着 後, 真空中, $1500^{\circ} \mathrm{Cで} 1.2 \mathrm{ks}$ 加熱して行った (16). 浸炭処 理村に含まれる炭素量は䄪 30 質量 $\mathrm{ppm}$ で, 炭素以外の元 素量は処理前後で后とんど同じで尔った，

引張試験は，インストロン型試験機を用いて行った。試 験温度は一196〜25ㄷ C゙，見かけのひずみ速度は $1.2 \times$ $10^{-3} \mathrm{~s}^{-1}$ とした，各試験温度に拁いて得た応力-変位曲線 上り，降伏強度（をたは $0.2 \%$ 酎力），破断強度（立たは引張 強度)招よび延性（全伸び）を算出した。李た破断後，走查 型電子顕微鏡を用いて破面観察を行い，破断様相，析出物 の有無等を調べた。

\section{III. 実験 結 果}

\section{1. 引張特性に及ぼすレニウムおよび炭素添加の効果}

Fig. 1 拉よびFig. 2 K, 再結晶処理材の強度拉よび延 性の温度依存性を示す。まず降伏強度については， $-30^{\circ} \mathrm{C}$ 以上の温度での降伏強度は 10 質量\%のレンウム量 付近で極小となる傾向がある。これに対して， $-70^{\circ} \mathrm{C}$ 以 下の温度での降伏強度はレニウム量とともに減少する傾向

Table 1 Chemical compositions of molybdenum and molybdeum-rhenium alloys.

\begin{tabular}{l|r|r|r|r|r|r|r|r|r|r|r|r|}
\hline \hline & \multicolumn{10}{|c|}{ (mass ppm) } & \multicolumn{1}{c|}{ (mass\%) } \\
\cline { 2 - 12 } & $\mathrm{O}$ & $\mathrm{N}$ & $\mathrm{C}$ & $\mathrm{Ca}$ & $\mathrm{Mg}$ & $\mathrm{Fe}$ & $\mathrm{Ni}$ & $\mathrm{Cr}$ & $\mathrm{Al}$ & $\mathrm{Si}$ & $\operatorname{Re}$ & Mo \\
\hline Mo & 14 & 4 & 6 & 3 & $<1$ & 30 & 5 & 11 & 7 & 20 & - & bal \\
Mo-2\%Re & 23 & 4 & 12 & 5 & 2 & 50 & 11 & 9 & 11 & 30 & 2 & bal \\
Mo-4\%Re & 15 & $<3$ & 7 & 4 & 2 & 30 & 10 & 8 & 7 & 30 & 4 & bal \\
Mo-10\%Re & 14 & $<3$ & 4 & 7 & 3 & 50 & 13 & 9 & 9 & 30 & 10 & bal \\
Mo-13\%Re & 20 & $<3$ & 7 & 7 & 3 & 60 & 11 & 9 & 11 & 60 & 13 & bal \\
\hline
\end{tabular}

を示した，破断強度については，2４\%質量のレニウム 添加による变化は汪とんどみられなかったが，ー100〜 $-30^{\circ} \mathrm{C}$ 温度での強度がレニウム量とともに增加する傾

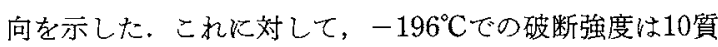
量\%付近で極大を示した。一方，延性については，

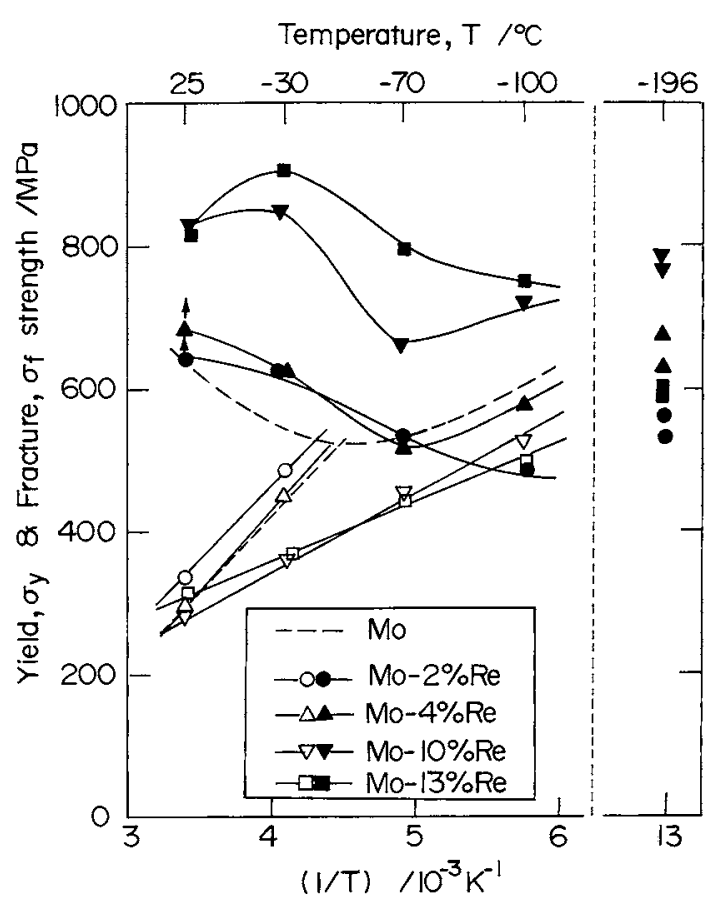

Fig. 1 Yield (open) and fracture strength (solid) at temperatures of -196 to $25^{\circ} \mathrm{C}$ of recrystallized Mo-Re alloys.

Temperature, $T /{ }^{\circ} \mathrm{C}$

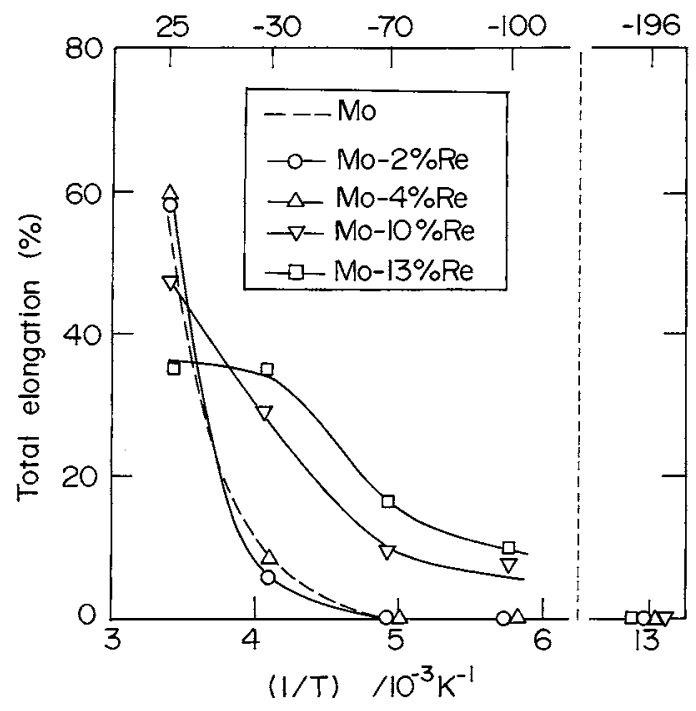

Fig. 2 Total elongation at temperatures of -196 to $25^{\circ} \mathrm{C}$ of recrystallized $\mathrm{Mo}-\mathrm{Re}$ alloys. 
-100〜 $-30^{\circ} \mathrm{C}$ の温度で, レニウム量とともに増加する傾

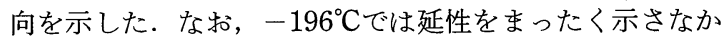
った. 以上の結果は，室温を除いて，Klopp とWitzke ${ }^{(7)}$ あるいは Lundberg ら ${ }^{(9)}$ の結果と扮持むね合っていた。な お。, Klopp と Witzkeのデータは $1315 \sim 1425^{\circ} \mathrm{C} て ゙$ 再結晶 させた棒状試験片に対するものであり, Lundberg らのは $1100 \sim 1500^{\circ} \mathrm{C}$ で再結晶させた板状試験片に対するもので あった。

Fig. 3 およびFig. 4 に，浸炭処理材に対する強度およ び延性の温度変化を示す. 再結晶処理材と比較して, 少量 の炭素添加により降伏強度, 破断強度および全伸びともに 全体的に増加した。しかしながら，レニウム依存性の傾向 は，再結晶処理材の場合と同様であった。なお，13質量

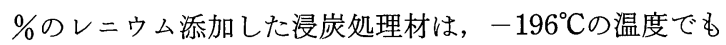
わずかの量ながら全伸びを示し，低温延性がきわめて良好 な材料であることが明らかにされた。

\section{2. 臨界応力および臨界温度の見積もり}

本研究に执いて，材料の低温に括ける強度および延性を 2 つのパラメータ, 臨界応力 $\left(\sigma_{\mathrm{c}}\right)$ 扎よび臨界温度 $\left(T_{\mathrm{c}}\right)$ で表 すことにする． $\sigma_{\mathrm{c}}$ 物よび $T_{\mathrm{c}}$ は，Fig. 5 に模式的に示すよ らに，降伏強度拉よび破断強度の両方の温度依存性により

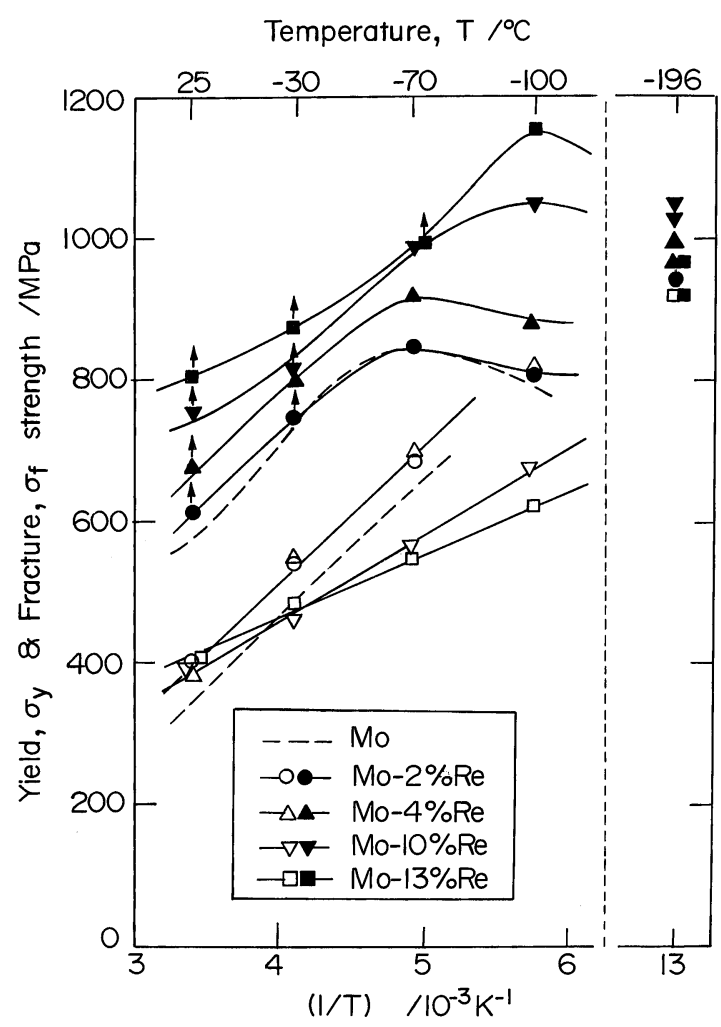

Fig. 3 Yield (open) and fracture strength (solid) at temperatures of -196 to $25^{\circ} \mathrm{C}$ of carburized Mo-Re alloys.
決定される，すなわち， $\sigma_{\mathrm{c}}$ は降伏強度が破断強度に等し くなる時の応力であり，低温に拈いてき裂が発生あるいは 伝ぱするために要する応力に対応すると考えられる。一 方， $T_{\mathrm{c}}$ は無延性遷移温度と呼ばれるものであり, その逆 数 $1 / T_{\mathrm{c}}$ は材料の低温延性の目安になる量である(15).

Fig. 6 特よびFig. 7 に，それぞれ $\sigma_{\mathrm{c}}$ 拉よび $T_{\mathrm{c}}$ とレニ ウム量の関係を示す。図中に Klopp とWitzke ${ }^{(7)}$ あるいは Lundberg ら ${ }^{(9)} の$ 結果も示した. 再結晶処理材の $\sigma_{\mathrm{c}}$ はレ ニウム量とともに増加し，10質量％付近で極大を示した. 本結果は, Klopp とWitzke(7) の $-125^{\circ} \mathrm{C}$ に拈ける破断強

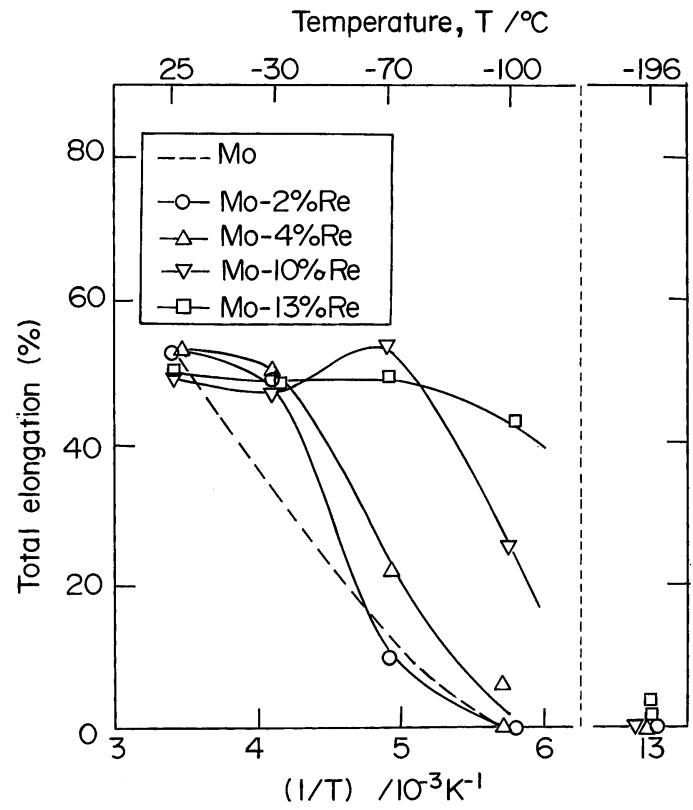

Fig. 4 Total elongation at temperatures of -196 to $25^{\circ} \mathrm{C}$ of carburized Mo-Re alloys.

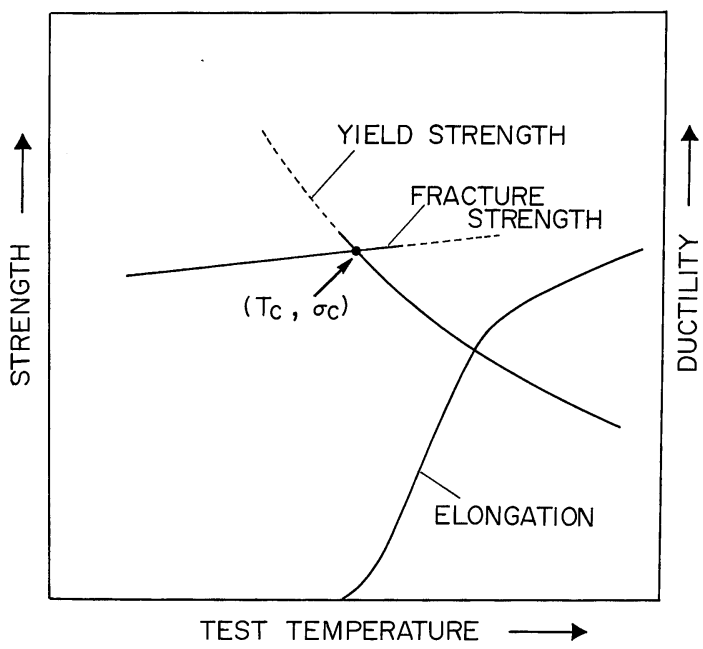

Fig. 5 Schematic drawing of temperature dependence in yield and fracture strength, and ductility. 


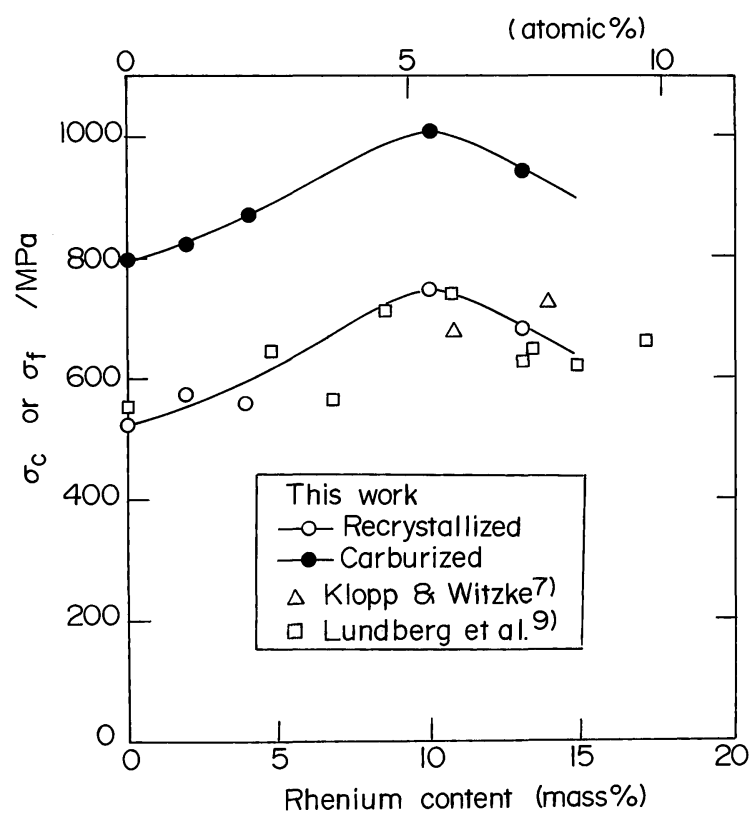

Fig. 6 Plots of critical stress $\sigma_{\mathrm{c}}$ in this work and fracture strength at low temperatures obtained previously as a function of rhenium content.

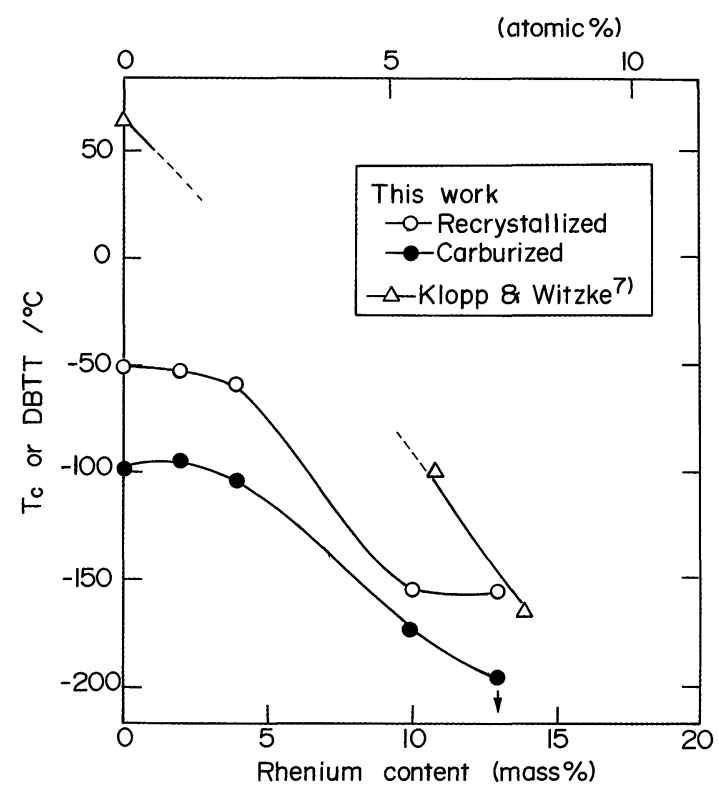

Fig. 7 Plots of critical temperature $T_{\mathrm{c}}$ in this work and DBTT obtained previously as a function of rhenium content.

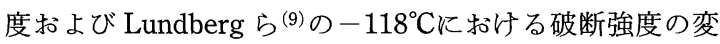

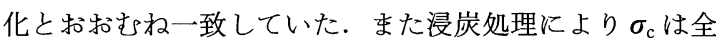
体的に約 $250 \mathrm{MPa}$ 増加したが，そのレニウム量依存性は 再結晶処理材のそれと同様であった。したがって，炭素添 加の効果は加算的であることが示唆された. 一方, 再結晶
処理材の $T_{\mathrm{c}}$ はレニウム量とともに低下したが， $\sigma_{\mathrm{c}}$ の変化 に対応して10～13質量\%あるいはそれ以上で極小值が現 れることが示唆された．また，浸炭処理により $T_{\mathrm{c}}$ は全体 的に低温側に移行したが，そのレニウム量依存性は再結晶 処理材のそれと注同様であった．以上の結果はKlopp と Witzke らの延性-脆性遷移温度(DBTT) の変化と定性 的に一致していた.

\section{3. 破面観察}

再結晶処理材括よび浸炭処理材の $-100^{\circ} \mathrm{C}$ に括ける引張 破断面を走查型電子顕微鏡により調べた．再結晶処理材の 場合，レニウム量に関係なく，破断様相は粒界破断が主で あり，粒界破面には析出物らしきものは全く観察できなか った．一方浸炭処理材の場合，破断様相は再結晶処理材と 異なり粒内破断が主となったが，き裂の開始点は結晶粒界 であった。また粒界破面に比較的微細な析出物(炭化物と 推測される)が観察された．破面写真より，全破断面積に 占める粒界破面の割合, すなわら粒界破面率 $\mathrm{PIF}($ Per cent Intergranular Fracture)を算出した．PIF は，再結晶 処理材で約 $80 \%$ ，浸炭処理材で約 $24 \%$ であり，レニウム 量に依存せずにほぼ一定であった。

\section{N. 考察}

\section{1. 低温破断強度に及ぼすレニウムおよび炭素添加の 効果}

Fig. 6 に示したように, 臨界応力 $\sigma_{\mathrm{c}}$ は再結晶処理材, 浸炭処理材ともにレニウム添加により増加し，10質量％ 付近で極大を示した．これは以下のように解釈される.

Fig. 8 に, 再結晶処理材, 浸炭処理材に対する粒界破 面率 PIF と $\sigma_{\mathrm{c}}$ の関係を示す. 図中の直線は炭素量の異な る純モリブデンに対して得た結果(14)であるが，この直線 関係はつぎのことを意味する，炭素量の増加によりモリブ デンの $\sigma_{\mathrm{c}}$ が増加し，PIF が減少する．これはへき開破断 強度が変わらず，主として粒界の破断強度だけが増加した ことによる. 本研究の場合，まず第一にレニウム添加によ

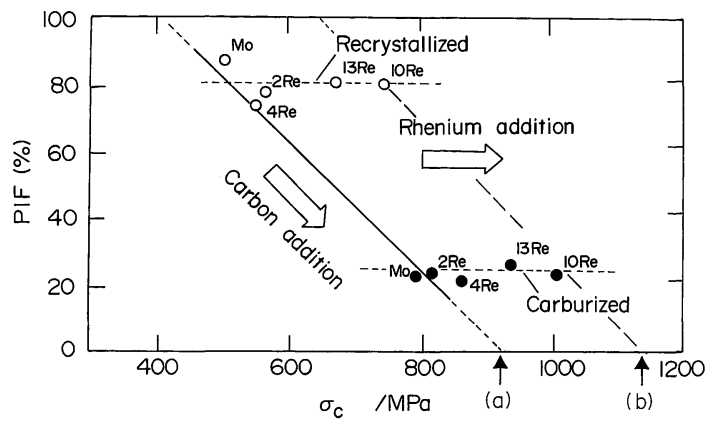

Fig. 8 Plots of percent intergranular fracture (PIF) as a function of $\sigma_{c}$ 
り $\sigma_{\mathrm{c}}$ は増加したが，PIF はほとんど変わらなかった。し たがって，レニウム添加により粒界破断強度とへき開破断 強度の両方が増加したことが示唆される. Hahn ら ${ }^{(17)}$ は, レニウム添加による延性改善が真のへき開破断強度, 粒界 破断強度の改善および塑性緩和のし易さによるものと推論 している. 本実験結果は, 彼らの推論を支持するものであ る. 第二に, 浸炭処理により $\sigma_{\mathrm{c}}$ は増加し，またPIF は大 きく減少した. これは, Mo-Re 合金においても炭素添加 により粒界破断強度がさらに増加（約 $250 \mathrm{MPa）したこと}$ を示唆する. その増加の割合は, 一定のレニウム量に対し て，純モリブデンの場合と同様であった，したがって，炭 素添加の効果は, III.2. でも示唆したように, レニウム効 果に対して加算的なものであることが考えられる.われわ れは以前の論文 ${ }^{(14)}$ に括いて，純モリブデンの見かけのへ き開破断強度が約 $920 \mathrm{MPa}$ (図中矢印(a)で示す)であるこ とを報告した。ここでいら見かけのへき開破断強度は, 結 晶粒径が $20 \sim 30 \mu \mathrm{m}$ の多結晶材料に拈いてき裂がある特 定の結晶粒界より発生した後，100\%粒内(へき開面)を通 って伝ぱするための応力を意味する. 本研究より,このよ らなへき開破断強度の改善は10質量\%のレニウム添加が 最も顕著であり (図中矢印 (b)で示す), 純モリブデンに比 べて約 $220 \mathrm{MPa}$ 上昇することが推論できた.

\section{2. 低温延性に及ぼすレニウムおよび炭素添加の効果}

Fig. 7 より，10１3質量％あるいはそれ以上のレニウ ム添加により臨界温度 $T_{\mathrm{c}}$ に極小が現れることが示唆され た.これは言い換えれば $1 / T_{\mathrm{c}}$ で代表される低温延性に極 大が現れることを示唆し，以下のように解釈される.

Fig. 9 に Mo-Re 合金の再結晶処理材, 浸炭処理材に対 する $1 / T_{\mathrm{c}}$ と $\sigma_{\mathrm{c}}$ の関係を示す. われわれは最近, 製造法, 化学組成あるいは熱処理の異なった純モりブデンおよびモ リブデン合金の低温破断挙動を調べた ${ }^{(18)}$. その結果, 図 中斜線で示すように, 材料の低温延性は主として $\sigma_{\mathrm{c}}$ 值に よって決まり, 前述したような要因による金属組織的変化 の影響は二義的であると考えられた． 4 質量\%以下のレニ ウム添加の場合, いずれのデータも図中の斜線に入り, 従 来の結果とよく合っていた．しかしながら，10質量\%以 上のレニウム添加した合金の場合, データは斜線に対して 上方に大きくずれた， $T_{\mathrm{c}}$ (あるいは $1 / T_{\mathrm{c}}$ ) は, Fig. 5 より 明らかなように, もとと破断強度 $\sigma_{\mathrm{f}}$ と降伏強度 $\sigma_{\mathrm{y}}$ の両 者の変化に依存する量である.しかしながら， Fig. 10 に 模式的に示すように，モリブデンに炭素を添加した場合， $\sigma_{\mathrm{f}}$ は大きく増加するが， $\sigma_{\mathrm{y}}$ の変化はそれに比して小さい. この限りに拉いて $1 / T_{\mathrm{c}}$ は主として $\sigma_{\mathrm{f}}$ の変化によって決 まり, 結果的に $1 / T_{\mathrm{c}}$ は臨界応力 $\sigma_{\mathrm{c}}$ に対して一義的に定 まるものと考えられる(矢印 1 と 2 の比較). ここで図中 の矢印 $(1,2,3,4)$ は, 各試料に対する $\left[\sigma_{\mathrm{c}}, 1 / T_{\mathrm{c}}\right]$ 值を示す. 一方, レニウムを添加した場合, 図で明らかなように, 低 温に拈いて $\sigma_{\mathrm{y}}$ の低下が著しい。これにより， $\sigma_{\mathrm{f}}$ は炭素添
加材と同程度であっても，1/ $T_{\mathrm{c}}$ は著しく増加する(矢印 1 と 3 , あるいは矢印 2 と 3 の比較) ことがわかる. レニウ ムと炭素の両方を添加した場合は, 以上のよらな効果が重 なり合った結果，1/ $T_{\mathrm{c}}$ はさらに増加する(矢印 1 と 4 の 比較). したがって, Fig. 9 で示されたよらな10～13質量 \%のレニウム添加した合金に括ける “異常さ”は，レニウ ム添加に起因した降伏強度の顕著な減少によるものと推論 される.な持，このよらな降伏強度の減少がレニウム添加 による固有の軟化作用と関連したものであるか否かは本研 究では明らかでない。

以上により，10１3質量\%あるいはそれ以上のレニウ

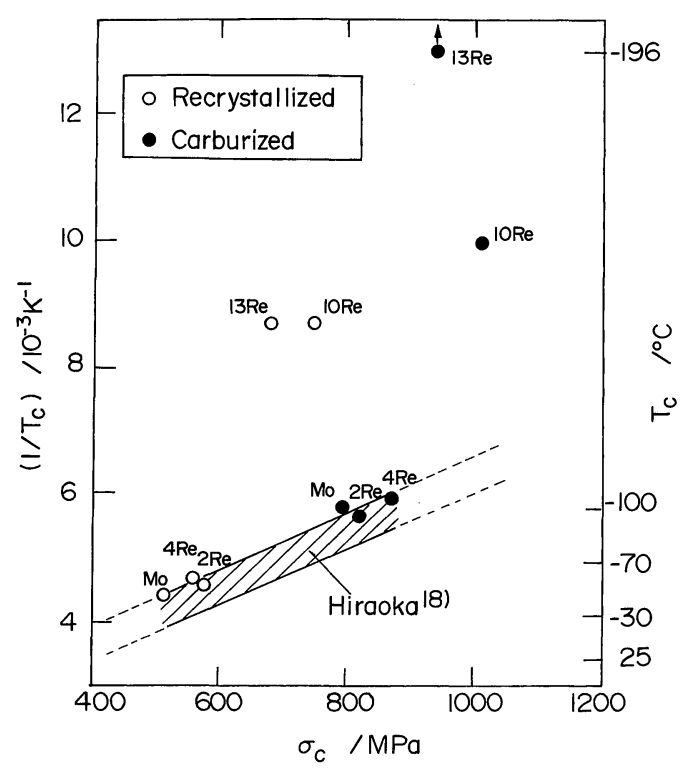

Fig. 9 Plots of $1 / T_{\mathrm{c}}$ as a function of $\sigma_{\mathrm{c}}$.

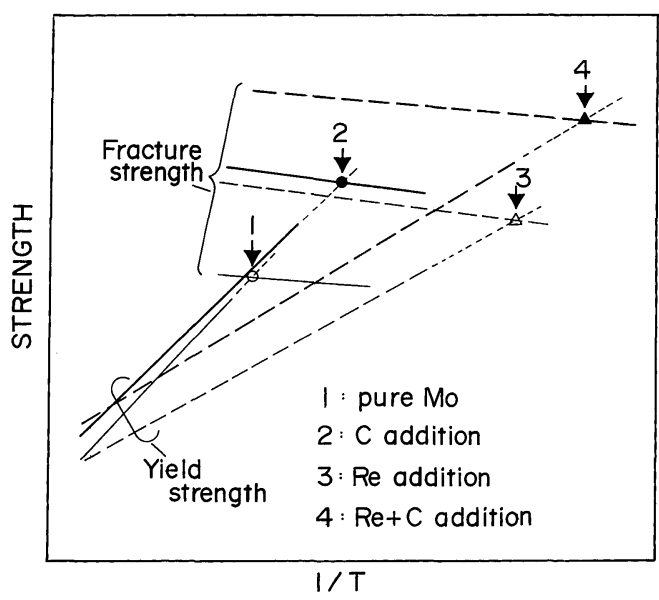

Fig. 10 Schematic relations between fracture strength and yield strength of molybdenum, and effects of carbon and rhenium additions on such a relation. 
ム添加により低温延性に極大が出現したのは， $\sigma_{\mathrm{c}}$ が10 質量\%のレニウム添加により極大となることと， $\sigma_{\mathrm{y}}$ がレ ニウム添加により䫒著に減少することの重なり合いの結果 生じるものと解釈される。また，炭素添加により，さらに 低温延性が改善したのは，粒界破断強度の上昇により $\sigma_{0}$ が増加したためと考觉られる。

\section{Wadsworth らの指摘に対する検討}

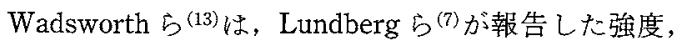
延性に対するレニウム効果は再結晶処理温度の違いに起因 した結晶粒径の違いとか炭素と酸素の原子量比 $\mathrm{C} / \mathrm{O}$ とい った組成の違いとかが重なり合ったものであり，本質的な ものではないと指摘した，そこで，Wadsworthらの指摘 の妥当性を検討するために，Fig. 11, Fig. 12 に本研究で 得た $\sigma_{\mathrm{c}}, T_{\mathrm{c}}$ ，扎よび Klopp と Witzke $\mathrm{e}^{(7)}$, Lundberg $5^{(9)}$ が 得た低温に打ける破断強度, 延性 (DBTT) と原子量比 C/ ○の関係を示卞. 本研究の浸炭処理材の破断強度は，再 結晶処理材のそれに比べて一般的に高い值を示したが，こ れは炭素添加による $\mathrm{C} / 0$ 值の堌加に対応したるのである。 しかしながら，全体的にみれば，破断強度と原子量比の間 には Wadsworth らが提案したよらな明瞭な相関性が認め られなかった。本研究の場合，原子量比は再結晶処理材で $0.4 \sim 0.7$, 浸炭処理材で1.7〜2.9であった。特に再結晶処 理材では結晶粒径が同じで，しかも原子量比がかなり小さ くまた材料間の違いが任とんどなかったにすかかわらず に， $\sigma_{\mathrm{c}}$ は明瞭なレニウム量低存性を示した。このことは

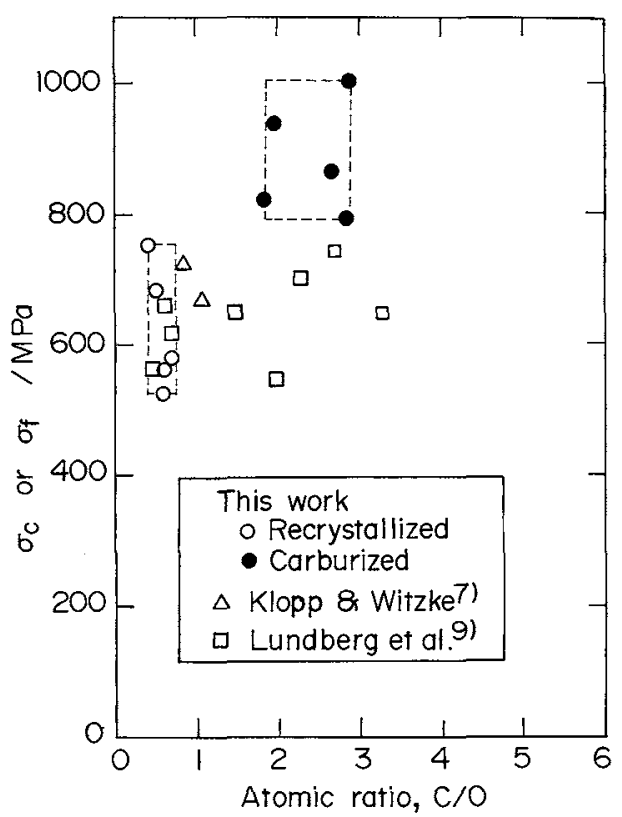

Fig. 11 Plots of $\sigma_{c}$ in this work and fracture strength at low temperatures obtained by Klopp and Witzke and by Lundberg et al. as a function of atomic ratio $\mathrm{C} / \mathrm{O}$.

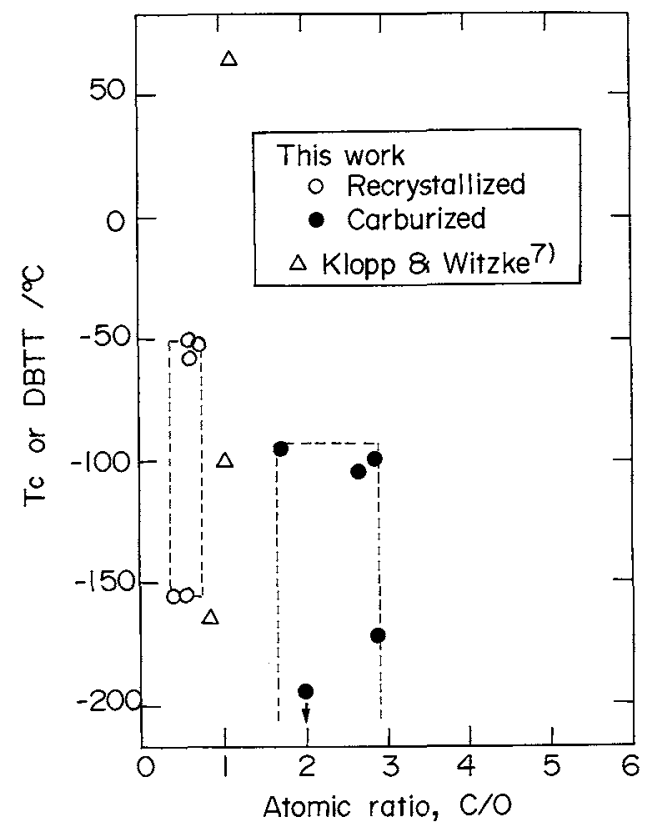

Fig. 12 Plots of $T_{\mathrm{c}}$ in this work and DBTT obtained by Klopp and Witzke as a function of atomic ratio $\mathrm{C} / \mathrm{O}$.

むしら，低温での破断強度が一定のレニウム量の添加に より極大となったのは本質的なものであり，Klopp

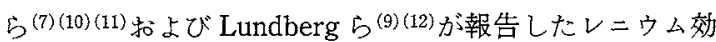
果を支持するものである。

一方， $T_{\mathrm{c}}$ に関しても， $\sigma_{\mathrm{c}}$ の場合と同様に，Wadsworth らの主張した原子量比との明膫な相関性が認められなかっ た.

\section{V. 結論}

粉末冶金モリブデンの低温に和计る破断挙動に及ぼすレ ニウム乱よび炭素添加の效果を調べた，結果をなとめると 以下のと乱りである。

（1）材料の低温に和ける臨界応力 $\left(\sigma_{\mathrm{c}}\right)$ は，10質量\%の レニウム添加により極大となった。これは，レニウム添加 により粒界破断強度とへき開破断強度の雨方が増加したた めである。また，炭素添加により $\sigma_{\mathrm{c}}$ がさらに増加したの は，粒界破断強度がさら火増加したためである。したがっ て，䈐素添加の效果はレニウム添加の效果に対して加算的 なものである。

（2）材料の低温延性 $\left(1 / T_{\mathrm{c}}\right)$ は，10～13質量\%あるいは そ和以上のレニウム添加により極大となることが示唆され た。これは，レニウム添加により(1)で述べたように低温で の破断強度が増加したことと，降伏強度が減少したことの 重なり合いの結果生じたものである。交た，炭素添加によ り低温延性がさらに改善されたが，これは $\sigma_{\mathrm{c}}$ が増加した 
ためである。

（3）材料の破断様相は，炭素添加により粒界破断型から へき開破断型に移行したが，レニウム添加によりほとんど 変化しなかった.

（4）本実験結果は, Klopp ら拈よび Lundberg らの強 度，延性に対するレニウム効果を支持するものである. ま た, レニウムを13質量\%添加し, さらに炭素を30質量 ppm 添加したモリブデン材料は, 非常にすぐれた低温延 性を持ら, 液体窒素温度に和いてもわずかながら全伸びを 示すことが明らかにされた。

Mo-Re 合金の試作に関して, 東京タングステン(侏に感 謝致します.

\section{文献}

(1) G. A. Geach and J. R. Hughes: Plansee Proc., Ed. F. Benesovsky, Pergamon Press, Oxford, (1956), p. 245.

(2) R. I. Jaffee, C. T. Sims and J. J. Harwood: Plansee Proc., Ed. F. Benesovsky, Pergamon Press, Oxford, (1959), p. 380.

(3) E. Votava: Acta Metall., 10(1962), 745.

(4) A. Lawley and R. Maddin: Trans. Am. Inst. Min. Eng., 224(1962), 573.

( 5 ) E. M. Savitskii, M. A. Tylkina and K. B. Povarova:
Rhenium Alloys, Nauka Publ. House, Moscow, (1965); Trans. JPRS No. 34, U. S. Dept. Commerce, (March 1966), p. 566.

(6) D. L. Davidson and F. R. Brontzen: J. Appl. Phys., 39(1968), 5768.

( 7 ) W. D. Klopp and W. R. Witzke: National Aeronautics and Space Administration, Report No. NASA TM X-2576, (1972).

( 8 ) G. G. Kurdyumova, Yu. V. Milman, V. A. Moskalenko, Startsev and V. P. Trefilov: Fiz.-Khim. Svoistva Reniya, Nauk, Moscow, (1979), p. 33.

( 9 ) L. B. Lundberg, E. K. Ohriner, S. M. Tuominen, E. P. Whelan and J. A. Shields, Jr.: Physical Metallurgy and Technology of Molybdenum and Its Alloys, Eds. K. H. Miska et al., AMAX, Ann Arbor, MI, (1985), p. 71.

(10) J. R. Stephens and W. R. Witzke: J. Less-Common Metals, 29(1972), 371.

(11) W. D. Klopp and W. R. Witzke: Metall. Trans., 4 (1973), 2006.

(12) L. B. Lundberg: J. Metals, 37 (1985), 44.

(13) J. Wadsworth, T. G. Nieh and J. J. Stephens: Scripta Metall., 20 (1986), 637.

(14) Y. Hiraoka, M. Okada and R. Watanabe: J. LessCommon Metals, 75(1980), 31.

（15）例えば, 平岡 裕, 入江宏定, 岡田雅年 : 溶接学会 論文集，5(1987), 522 .

(16) Y. Hiraoka, F. Morito, M. Okada and R. Watanabe: J. Nucl. Mater., 78(1978), 192.

(17) G. T. Hahn, A. Gilbert and R. I. Jaffee: in Refractory Matals and Alloys II, Metall. Soc. Conf. Vol. 17 (1962), 23.

(18) Y. Hiraoka: Mater. Trans., JIM, 31(1990), 861. 